\title{
Pengaruh Konsolidasi Lahan Perkotaan terhadap Harga Tanah di Ringintelu, Kelurahan Kalipancur - Kota Semarang
}

\author{
Wuri Mulyanti ${ }^{1}$
}

Diterima : 19 Desember 2014

Disetujui : 5 Januari 2015

\begin{abstract}
Changes in Semarang city is marked by the process of urbanism as an increased need caused widespread land settlements, economic facilities, trade and services as well as network infrastructure. This causes physical changes in the environment and the seizure of the land so that the price of land had become unmanageable. One of the government's efforts to unravel this problem is the structuring of the environment through urban land consolidation program. The program is expected to increase the price of the land, so it will not show the existence of idle land / "idle land" as in other research sites. It is what lies behind the importance of research on the effects of urban land consolidation in Ringintelu, Kalipancur Village - Semarang. The goal is to assess the effect of urban land consolidation on the price of land in Ringintelu, Kalipancur Village - Semarang. Methods this study uses a quantitative approach to factor analysis, multiple regression crosstab and to determine the level of the relationship and influence. The results obtained in this study is the relationship between land consolidation with the price of land in Ringintelu, Kalipancur Village - Semarang. This relationship affects 81.1 to rising land prices by $400 \%$ to $900 \%$ which are not directly affected by the consolidation program. The influence is said to be directly due to factors such as accessibility and infrastructure development occurs as a result of land consolidation program as well as the influence of other factors.
\end{abstract}

Key words : land consolidation, land price, market price

\begin{abstract}
ABSTRAK
Perubahan kota Semarang salah satunya ditandai melalui proses pengkotaan seperti peningkatan kebutuhan lahan yang disebabkan meluasnya pemukiman, fasilitas ekonomi, perdagangan dan jasa serta jaringan infrastruktur. Hal ini menyebabkan terjadinya perubahan fisik lingkungan dan perebutan lahan sehingga harga tanah menjadi tidak terkendali. Salah satu upaya pemerintah untuk mengurai permasalahan ini adalah penataan lingkungan melalui program konsolidasi lahan perkotaan. Program ini diharapkan mampu meningkatkan harga tanah yang ada, sehingga tidak akan muncul adanya lahan tidur/"idle land" seperti di lokasi peneltian. Hal inilah yang melatarbelakangi pentingnya penelitian mengenai pengaruh konsolidasi lahan perkotaan di Ringintelu, Kelurahan Kalipancur - Kota Semarang. Tujuannya adalah mengkaji pengaruh konsolidasi lahan perkotaan terhadap harga tanah di Ringintelu, Kelurahan Kalipancur - Kota Semarang. Metode penelitian ini menggunakan pendekatan kuantitatif dengan analisis faktor, crosstab dan regresi berganda untuk mengetahui tingkat hubungan dan pengaruhnya. Hasil yang diperoleh dalam penelitian ini adalah adanya hubungan antara konsolidasi lahan dengan harga tanah di Ringintelu Kelurahan Kalipancur Kota Semarang. Hubungan ini berpengaruh sebesar 81,1 terhadap kenaikan harga tanah sebesar 400\% hingga 900\% yang secara tidak langsung dipengaruhi oleh adanya program konsolidasi. Pengaruh dikatakan tidak langsung karena faktor-faktor seperti aksesibilitas dan pengembangan sarana dan prasarana terjadi sebagai akibat adanya program konsolidasi lahan selain juga karena pengaruh faktor lainnya.
\end{abstract}

Kata kunci : konsolidasi lahan, harga tanah, harga pasar

\footnotetext{
${ }^{1}$ Staf Bidang Pengaturan dan Penataan Pertanahan Kanwil BPN Provinsi Jawa Tengah Kontak Penulis: wie_ruwie@yahoo.co.id
} 


\section{PENDAHULUAN}

Perubahan kota seperti halnya di Kota Semarang ditandai melalui proses pengkotaan ditandai dengan peningkatan kebutuhan lahan yang disebabkan meluasnya pemukiman, fasilitas ekonomi, perdagangan dan jasa serta jaringan infrastruktur. Hal ini menyebabkan terjadinya perubahan fisik lingkungan. Kondisi ini karena adanya pertambahan penduduk, urbanisasi dan perkembangan aktivitas penduduk yang mengakibatkan kota berkembang semakin pesat dan berdampak bagi kehidupan lingkungan perkotaan. Persaingan yang ketat dalam perebutan lahan sebagai upaya pemanfaatan ruang oleh kegiatan kota muncul. Perebutan lahan tidak terelakkan sehingga harga tanahpun menjadi tidak terkendali. Salah satu upaya pemerintah untuk mengurai permasalahan ini adalah penataan lingkungan melalui program konsolidasi lahan perkotaan. Program konsolidasi lahan ini diharapkan mampu meningkatkan harga tanah yang ada, sehingga tidak akan muncul adanya lahan tidur/"idle land" seperti di lokasi penelitian. Hal inilah yang melatarbelakangi pentingnya penelitian mengenai pengaruh konsolidasi lahan perkotaan di Ringintelu, Kelurahan Kalipancur Kota Semarang.

Berdasarkan latar belakang dan permasalahan tersebut maka rumusan masalah dalam tulisan ini adalah "Bagaimana hubungan konsolidasi lahan perkotaan dengan harga tanah di Ringintelu, Kelurahan Kalipancur Kota Semarang?”.

Tujuan penelitian ini adalah mengkaji pengaruh konsolidasi lahan perkotaan terhadap harga tanah di Ringintelu, Kelurahan Kalipancur Kota Semarang. Adapun sasaran dalam penelitian ini adalah: 1) Mengidentifikasi pelaksanaan konsolidasi lahan perkotaan di Ringintelu, Kelurahan Kalipancur Kota Semarang, 2) Menganalisis factor/variabel yang berpengaruh terhadap harga tanah dalam konsolidasi lahan di Ringintelu, Kelurahan Kalipancur Kota Semarang, 3) Menganalisis hubungan kausallistik antara konsolidasi lahan perkotaan dan harga tanah di Ringintelu, Kelurahan Kalipancur Kota Semarang, 4) Merumuskan pengaruh konsolidasi lahan terhadap harga tanah di Ringintelu, Kelurahan Kalipancur Kota Semarang, 5) Merekomendasikan keterkaitan konsolidasi lahan dengan harga tanah.

\section{METODE PENELITIAN}

Penelitian ini menggunakan pendekatan positivistik-rasionalistik. Metode analisisnya menggunakan metode kuantitatif yang di dalamnya terdapat variabel-variabel dan termasuk dalam format eksplanasi survei. Data yang dibutuhkan berupa data tentang kondisi lokasi penelitian, pelaksanaan konsolidasi lahan di lokasi penelitian dan data tentang harga tanah sebelum maupun sesudah konsolidasi lahan selesai dilakukan. Analisis dilakukan menggunakan software komputer spss 17 meliputi analisis faktor untuk mengetahui faktor-faktor yang berpengaruh terhadap harga tanah, crosstab dan regresi berganda untuk hubungan kausalistik konsolidasi lahan dengan harga tanah.

\section{GAMBARAN UMUM KONSOLIDASI LAHAN DAN HARGA TANAH DI RINGINTELU}

Konsolidasi lahan di Ringintelu berdasarkan data BPN (2008) adalah konsolidasi lahan yang dilakukan pada tanah negara bekas hak guna bangunan yang dimiliki oleh 100 orang dan terdiri dari 100 bidang tanah dengan kondisi terbangun sebanyak 19 bidang. Obyek konsolidasi tanah adalah seluas $\pm 9.467 \mathrm{~m} 2$ yang ditegaskan dalam SK Kakanwil BPN Provinsi Jawa Tengah no. 05/Peneg/APBN/KTP/2008 tanggal 23 Mei 2008 dengan batas yaitu sebelah utara saluran air/tol 
Krapyak dan HGU PT Alka dan tanah negara berupa lahan kosong, sebelah timur berupa tanah negara, sebelah selatan saluran air dan sebelah barat tanah HGU PT Aldas dan PT Alka.

Konsolidasi lahan perkotaan ini selain dilakukan oleh 100 peserta dengan menggunakan dana APBN dan dana swadaya oleh pemilik 51 persil bidang tanah. Obyek konsolidasi lahan swadaya ini terdiri dari 21 bidang tanah dengan luas $1.368 \mathrm{~m} 2$ dengan 15 bidang tanah sudah terbangun dan $2.099 \mathrm{~m} 2$ meliputi 30 bidang tanah. Tanah semula merupakan tanah HGB dan Tanah eigendom. Lebih jelasnya dapat dilihat pada Gambar 1 dan Gambar 2.

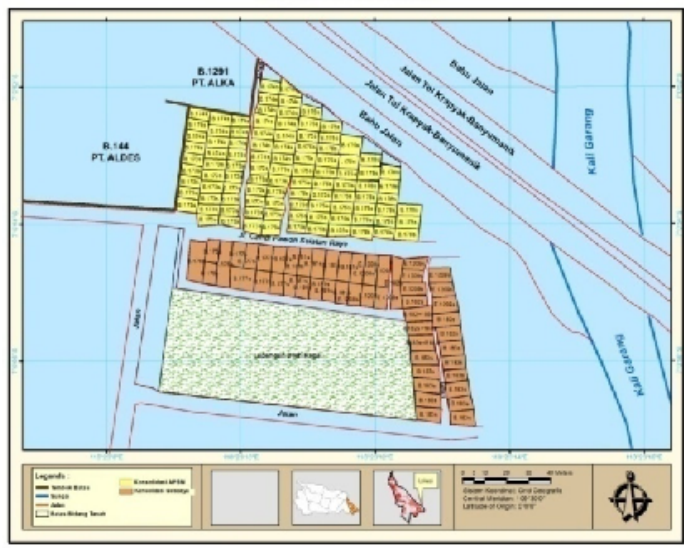

Sumber: BPN Kota Semarang

GAMBAR 1

PETA LOKASI KONSOLIDASI LAHAN APBN DAN SWADAYA
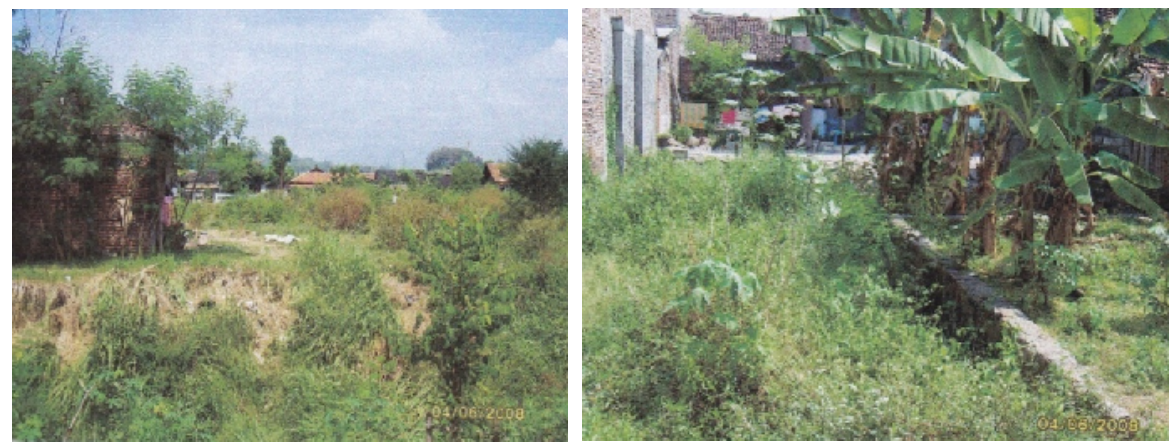

Sumber: BPN Kota Semarang

\section{GAMBAR 2 \\ KAWASAN RINGINTELU SEBELUM KONSOLIDASI LAHAN}

Pengembangan fisik pada lokasi konsolidasi lahan APBN maupun swadaya di Ringintelu, setelah pelaksanaan konsolidasi lahan antara lain meliputi:

1. Jalan, jalan di bangun sebagai elemen pertama mengikuti persil dengan lebar jalan utama $6 \mathrm{~m}$ dan 2-2,5meter untuk jalan masuk gang. Semua persil didesain menghadap ke jalan dengan perkerasan jalan dilakukan dengan menggunakan aspal pada jalan utama dan paving pada gang rumah.

2. Talud, talud dan drainse dibuat dengan beton. Lebar drainase jalan utama adalah $50 \mathrm{~cm}$ dan untuk jalan masuk gang lebar $20 \mathrm{~cm}$.

3. Air bersih, dengan bantuan pemerintah telah disediakam air bersih berupa penampungan air dan aliran PDAM. 
4. Ruang terbuka, sebagian dari STUP dimanfaatkan sebagai ruang terbuka seperti taman, balai RT, dan pos keamanan.

5. Balai RT dan pos penjagaan, STUP sebagian dimanfaatkan sebagai lokasi balai RT yang dengan batuan dana dari pemerintah kota serta swadaya peserta konsolidasi tanah konstruksi balai RT sudah terbangun dan sebagai lokasi IPAL.

Lokasi konsolidasi lahan yang merupakan lokasi relokasi, semula adalah tanah negara hak guna bangunan dan tanah eigendom. Sebelum dilakukan konsolidasi tanah, tanah berbentuk bidangbidang tanah yang tidak semuanya mendapat akses ke jalan. Tanah diperoleh dengan pembiayaan yang dibantu oleh pemerintah dan yayasan YSS. Setelah dilakukan konsolidasi lahan, tanah menjadi tertata dan semua mendapat akses ke jalan. Lebih jelasnya dapat dilihat pada Gambar 3.

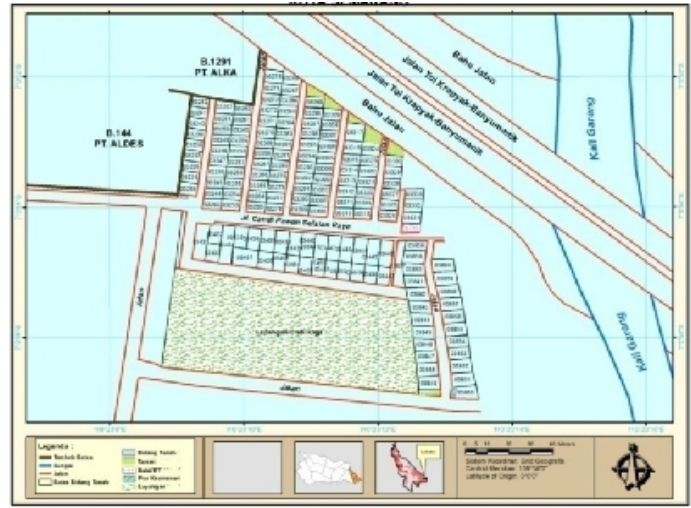

Sumber: Kantor Pertanahan Kota Semarang, 2010

GAMBAR 3

PETA SESUDAH KONSOLIDASI LAHAN
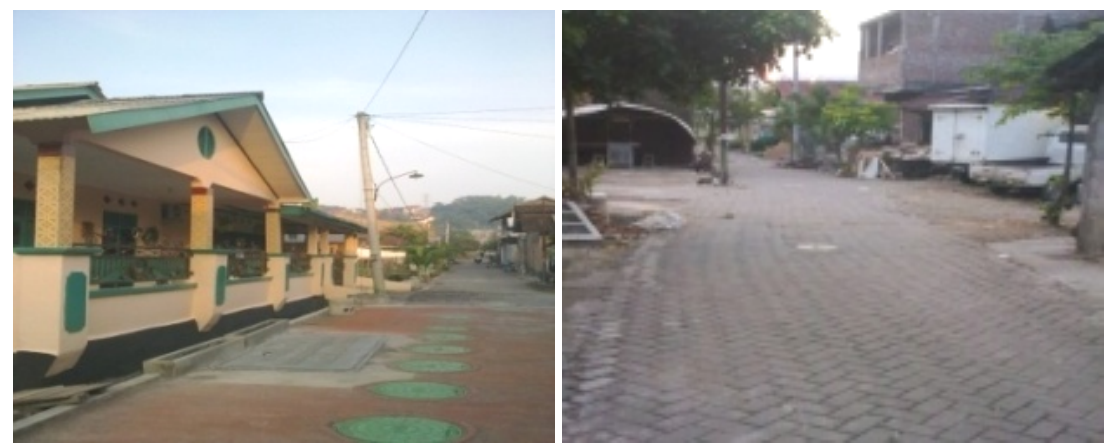

Sumber: Survei, 2013

GAMBAR 4

KAWASAN RINGINTELU SESUDAH KONSOLIDASI LAHAN

Harga tanah dimaksud dalam penelitian ini adalah harga pasar. Harga pasar diperoleh berdasar transaksi yang terjadi sebelum dan sesudah konsolidasi lahan serta berdasar informasi dari makelar/spekulan tanah serta dari para responden. Harga transaksi pada lokasi konsolidasi lahan APBN sebelum program konsolidasi lahan dilakukan berada jauh di bawah NJOP maupun ZNT. Harga tanah sebelum dilakukannya konsolidasi lahan berada pada angka Rp.75.000,Rp.100.000,- dan Rp.200.000,-. Sedangkan NJOP pada lokasi konsolidasi adalah Rp.200.000.dan ZNT berada pada kisaran Rp.500.000,- hingga Rp.750.000,-. 
Terdapat 5 kelompok harga yaitu Rp.850.000,- Rp.900.000,- Rp.1.000.000,- Rp.1.100.000,- dan Rp.1.200.000,-. Harga ini jauh berada di atas NJOP maupun ZNT yang dikeluarkan oleh BPN. Terdapat deviasi antara harga pasar dengan rentang tertinggi harga berdasar dari ZNT (Rp.750.000) yaitu sebesar Rp.100.000,- atau 13,3\%, Rp.150.000,- atau 20\%, Rp.250.000,- atau 33,3\%, Rp.350.000,- atau 46,6\% dan dan Rp.450.000,- atau 60,0\%. Sebaran harga tanah di lokasi penelitian dapat dilihat pada Gambar 3 berikut.

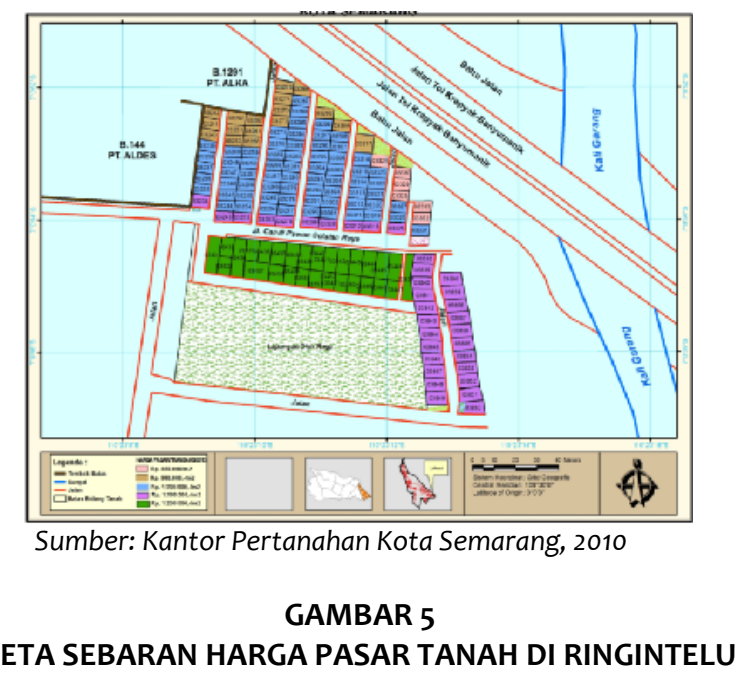

\section{KAJIAN KONSOLIDASI LAHAN DAN PENGARUHNYA TERHADAP HARGA TANAH}

\section{Tanah dan Lahan}

Lahan (site) adalah permukaan daratan dengan kekayaan benda padat, cair dan gas, sedangkan tanah (soil) yang dimaksud dalam hal ini adalah benda yang berwujud padat, cair dan gas yang tersusun oleh bahan organik dan anorganik yang terdapat dalam tanah. Tanah banyak dijadikan sebagai barang investasi yang menguntungkan dan sekaligus mendorong untuk melakukan spekulasi karena di satu aspek ketersediaan lahan tersebut, sedangkan di aspek lain permintaan akan lahan semakin bertambah terus, sehingga mengakibatkan harga tanah menjadi mahal terutama bila berdekatan dengan pusat-pusat kota (Sumardjono, 2001).

Tanah dalam UUPA pasal 4 ayat 1 secara yuridis dijelaskan bahwa tanah merupakan perwujudan bumi bagian permukaan. Suatu sumber daya yang menyediakan ruangan yang dapat mendukung semua kebutuhan makhluk hidup. Pada dasarnya ruangan yang disediakan sangat terbatas, sementara itu kebutuhan akan tanah mempunyai kecenderungan yang terus meningkat dari tahun ke tahun, baik untuk kebutuhan perumahan, pertanian, industri dan lain sebagainya. Hal ini seperti dalam PP nomor 24 tahun 1997 tentang pendaftaran tanah, yang mendefinisikan bidang tanah adalah bagian permukaan bumi yang merupakan satuan bidang terbatas.

Tanah atau lahan mempunyai kekuatan ekonomis di mana nilai atau harga tanah sangat tergantung pada penawaran dan permintaan. Dalam jangka pendek penawaran sangat inelastis, ini berarti harga tanah pada wilayah tertentu akan tergantung pada faktor permintaan, seperti kepadatan penduduk dan tingkat pertumbuhannya, tingkat kesempatan kerja dan tingkat pendapatan masyarakat serta kapasitas sistem transportasi dan tingkat suku bunga (Eckert, 1990). 
Kata lahan yang dimaksud dalam penelitian ini adalah lebih kepada tanah dalam arti ruang daratan (land). Jadi, lahan merupakan bagian dari pengertian ruang karena ruang didefinisikan lebih luas dari tanah, yaitu terdiri atas ruang daratan (tanah), ruang perairan, dan ruang udara. Oleh karena itu dalam konteks penelitian ini "pengertian lahan adalah sama dengan tanah dan pemanfaatan diatasnya karena kata tanah dimaksud merupakan bentang tanah yang sudah jelas penggunaannya yaitu untuk permukiman".

\section{Konsolidasi Lahan}

Konsolidasi Tanah/lahan adalah suatu model pembangunan yang berkaitan dengan masalah kebijakan pengendalian tanah untuk kepentingan jalan dan prasarana unum lainnya, yang merupakan salah satu unsur dalam pembangunan tersebut (Yuriwin, 2010). Program konsolidasi tanah yang dilaksanakan di Indonesia merupakan fenomena diperlukannya penyelesaian bijaksana dari pengambil kebijakan sebagai upaya penataan ruang yang meminimalkan potensi konflik.

Konsep konsolidasi tanah perkotaan menurut Oloan Sitorus (2008) adalah merupakan kebijakan pertanahan di wilayah perkotaan (urban) dan pinggiran kota (urban fringe) mengenai penataan kembali penguasaan dan penggunaan tanah sesuai dengan rencana tata ruang serta usaha pengadaan tanah untuk kepentingan pembangunan guna peningkatan kualitas lingkungan hidup dengan partisipasi masyarakat. Pengertian lain juga mengatakan bahwa konsolidasi tanah adalah suatu model pembangunan yang mengatur semua bentuk tanah yang semula terpecah-pecah dan dengan bentuk yang tidak teratur menjadi tanah-tanah yang bentuknya dan tata letaknya teratur (Setiawan, 2008).

Pengertian dan konsep Konsolidasi Tanah (KT) sebagaimana dimuat dalam Peraturan Kepala Badan Pertanahan Nasional Nomor 4 Tahun 1991, tentang Konsolidasi Tanah, dan yang menjadi dasar pelaksanaan konsolidasi tanah di Indonesia hingga saat ini adalah kebijakan pertanahan mengenai penataan kembali penguasaan, pemilikan, penggunaan dan pemanfaatan tanah serta usaha pengadaan tanah untuk kepentingan pembangunan untuk meningkatkan kualitas lingkungan dan pemeliharaan sumberdaya alam dengan melibatkan partisipasi aktif masyarakat.

Berdasarkan pengertian di atas maka pemakaian istilah konsolidasi lahan penelitian ini adalah setara dengan konsolidasi tanah. Istilah konsolidasi lahan dipakai dalam penelitian ini karena obyek konsolidasi adalah tanah di perkotaan dengan peruntukan pasti yaitu untuk permukiman.

Pengertian diatas disimpulkam bahwa terdapat empat unsur, antara lain:

a. Unsur penataan penguasaan dan penggunaan bidang-bidang tanah,

b. Unsur pengadaan tanah untuk kepentingan pembangunan,

c. Unsur meningkatkan kualitas lingkungan dan pemeliharaan sumber daya alam,

d. Unsur partisipasi masyarakat,

Tujuan dari konsolidasi tanah sendiri meliputi 3 (tiga) hal yaitu: tercapainya pemanfaatan tanah secara optimal, mendorong partisipasi aktif masyarakat dalam pembangunan secara bersama, dan meningkatkan efisiensi penggunaan tanah dan pemantapan kepastian hukum pemilik tanah melalui penataan penggunaan dan penguasaan tanah. 
Manfaat dari konsolidasi tanah antara lain adalah:

a. mempercepat penyelesaian pembangunan prasarana dan fasilitas perkotaan yang sesuai dengan tata ruang dan dilakukan secara berkesinambungan,

b. meningkatkan daya guna tanah (persil tidak beraturan menjadi teratur),

c. menghemat pengeluaran pemerintah untuk ganti rugi tanah dan biaya pembangunan prasarana dan fasilitas kota, (biaya ditanggung secara bersama)

d. meskipun akan terjadi pengurangan luas pemilikan tanah, akan tetapi nilai dan daya dukung tanah akan semakin meningkat

e. menghindari dan mengurangi pemindahan penduduk dari lokasi semula (bencana), karena setelah konsolidasi tanah para pemilik akan menerima kembali tanahnya dalam bentuk dan kondisi yang lebih menguntungkan

f. meningkatkan partrisipasi masyarakat dalam pembangunan sekaligus mengurangi kerawanan sosial akibat perbedaan lingkungan permukiman

g. mempercepat kegiatan administrasi pertanahan dan menunjang sistem perpajakan tanah yang lebih akurat dan lebih adil

h. persil -persil tanah pengganti biaya pembangunan dapat dimanfaatkan untuk kepentingan penyediaan tanah murah

i. tanah yang sudah dikonsolidasi dapat dibangun sendiri oleh pemiliknya atau pemerintah dalam bentuk bantuan kredit atau hibah

j. mencegah spekulasi dan kenaikan harga tanah karena dapat dinikmati langsung oleh pemilik asli sehingga mendorong kestabilan harga tanah

Sasaran konsolidasi tanah difokuskan demi tercapainya tatanan penguasaan dan penggunaan lahan yang tertib dan teratur. Melalui penataaan tanah secara fisik dan aspek hukumnya, akan diperoleh ketertiban legalitas atas penguasaan tanah karena disertai kelengkapan tanda bukti hak atas tanah (sertipikat tanah).

Pada Prinsipnya konsolidasi lahan/tanah (KaBPN no 4/1991), meliputi:

a. Kegiatan pembangunan oleh rakyat, dari rakyat dan untuk rakyat,

b. Dapat dikerjasamakan dengan pihak lain. Dalam hal ini disamping pembiayaan konsolidasi tanah pembiayaannya dapat bersumber dari APBN, APBD, serta Swadaya/PNBP juga dapat dibiayai melalui pihak ketiga/developer, terlebih pada fase pasca konsolidasi tanah,

c. Kesepakatan $85 \%$ peserta untuk Sumbangan Tanah Untuk Pembangunan (STUP),

d. Tanah Pengganti Biaya Pelaksanaan (TPBP),

e. Kepastian hak atas tanah dengan lingkungan yang tertata.

Konsolidasi Tanah merupakan program pertanahan yang diselenggarakan berdasarkan azas (KaBPN no 4 tahun 1991): kesepakatan, pelaksanaan didasarkan atas dari, oleh dan untuk rakyat/peserta; peran serta, konsolidasi hanya akan berhasil dengan peran serta masyarakat manfaat, hasil yang dicapai melalui konsolidasi tanah akan bermanfaat baik untuk peserta, maupun pemerintah; keadilan, artinya bahwa diantara peserta konsolidasi tanah diberlakukan sama, sama-sama memberikan sumbangan tanah untuk pembangunan, dan lain-lain; transparan, artinya bahwa dari sejak perencanaan hingga pasca konsolidasi tanah secara bersama-sama peserta diikut sertakan; kepastian hukum, artinya bahwa hasil akhir yang berwujud penataan bidang-bidang tanah juga diterbitkannya legalitas aspek (sertifikat tanah) yang merupakan alas hak yang akan dimiliki semua peserta konsolidasi tanah; akuntabilitas segala sesuatunya dapat dipertanggung jawabkan; membangun tanpa menggusur.

Hasil pelaksanaan konsolidasi tanah (KaBPN no. 4 Tahun 1991) meliputi:

a. Tertatanya penggunaan, penguasaan dan pemilikan tanah 
b. Terbangunnya sarana fisik lingkungan (jalan, fasos dan fasum))

c. Tersedianya ruang-ruang terbuka

d. Adanya kepastian hukum atas kepemilikan tanah bagi peserta konsolidasi.

Apabila melihat dari hasil pelaksanaan konsolidasi tersebut maka dapat dikatakan bahwa konsolidasi diharapkan dapat menaikkan harga/nilai tanah di wilayah perencanaan. Oleh karena itu perlu kajian lebih lanjut tentang harga tanah pasca penataan konsolidasi tanah.

\section{Harga Tanah}

Harga tanah salah satunya ditentukan oleh lokasi/letak. Karenanya banyak orang mencari tanah untuk lokasi perumahan berdasar berbagai aspek. Lokasi daerah perumahan itu sendiri menurut Mirhad (1983, dalam Sadyohutomo 2008), dapat ditinjau dari empat aspek yaitu:

1. Ditinjau dari segi teknis pelaksanaannya

Lokasi daerah perumahan hendaknya yang mudah mengerjakan dan bukan daerah rawan bencana. Selain itu lokasi juga mudah dicapai dengan tanah yang baik sehingga konstruksi bangunan yang ada dapat direncanakan dengan system yang semurah mungkin. Sumber air bersih, listrik, pembuangan air limbah/kotor/hujan (drainase) dan lain-lain mudah didapatkan. Bahan-bahan bangunan beserta tebaga kerjanya juga hendaknya mudah didapatkan.

2. Dilihat dari segi tata guna tanah

Tanah yang secara ekonomis sudah sukar dikembangkan secara produktif dan tidak merusak lingkungan existing, bahkan kalau bisa memperbaikinya.

3. Dilihat dari segi kesehatan dan kemudahan, Lokasi perumahan hendaklah jauh dari industri, tidak terganggu kebisingan, dipilih yang udaranya masih sehat, mudah mendapatkan pendukung/sumber infrastruktur serta lokasi mudah dicapai dari pusat aktivitas.

4. Ditinjau dari segi politis dan ekonomi

Lokasi perumahan harus menciptakan kesempatan kerja bagi masyarakat sekelilingnya, Sebagai perumahan/kawasan yang sehat dan bersih serta mudah penjualan karena lokasi yang disukai oleh calon pembeli.

Harga atas sebidang tanah dicerminkan oleh aliran-aliran keuntungan yang diterima atas pemakaian sebidang tanah tersebut. Keuntungan-keuntungan tersebut berkaitan dengan pengaruh lingkungan yang dapat dibedakan sebagai faktor manusia dan non manusia. Faktor manusia berkenaan dengan perbuatan manusia untuk mempertinggi harga tanah seperti mendirikan bangunan. Faktor non-manusia berkenaan dengan eksternalitas yang diterima oleh tanah tersebut. Jika eksternalitas positif, seperti dekat dengan pusat perekonomian, bebas banjir, kepadatan penduduk, dan adanya sarana jalan, maka tanah akan bernilai tinggi jika dibandingkan dengan tanah yang tidak menerima eksternalitas, meskipun luas dan bentuk tanah itu sama. Jika tanah menerima eksternalitas yang bersifat negatif, seperti dekat dengan sampah, jauh dari pusat kota/perekonomian, tidak bebas banjir, maka tanah akan berharga rendah jika dibandingkan dengan tanah yang tidak menerima eksternalitas negatif (Pearce and Turner 1990).

Harga tanah dalam konteks pasar properti adalah harga pasar wajar yaitu harga yang ditentukan atau ditetapkan oleh pembeli yang ingin membeli sesuatu dan penjual ingin menjual sesuatu berdasarkan persetujuan atau kesepakatan kedua belah pihak dalam kondisi wajar tanpa ada tekanan dari pihak luar pada proses transaksi jual beli sehingga terjadi kemufakatan. Pembeli dan penjual mempunyai tenggang waktu yang cukup atas properti yang diperjualbelikan dan bertindak untuk kepentingan sendiri. 
Harga pasar pada dasarnya mencerminkan harga yang terbaik atas suatu properti pada suatu waktu, tempat dan keadaan atau kondisi pasar tertentu. Hal ini sejalan dengan pengertian nilai menurut Eckert (1990) yang menyebutkan bahwa nilai merupakan suatu waktu yang menggambarkan harga atau nilai uang dari properti, barang atau jasa bagi pembeli dan penjual. Dari beberapa pengertian dapat disimpulkan bahwa harga tanah adalah ukuran kemampuan tanah untuk menghasilkan atau memproduksi sesuatu secara langsung memberikan keuntungan ekonomis. Dalam konteks pasar properti nilai tanah sama dengan harga pasar tanah tersebut misalnya harga pasar tanah tinggi maka nilai tanahnya juga tinggi demikian pula sebaliknya. Noor (1997) mendefinisikan penilaian sebagai suatu penaksiran dan pendapat atas nilai dari suatu harta tanah oleh seorang penilai yang didasari intrepretasi dari faktor-faktor dan keyakinan pada waktu atau tanggal tertentu.

Interaksi faktor-faktor tersebut di atas menciptakan nilai yang tercermin dalam prinsip ekonomi permintaan dan penawaran. Permintaan suatu komoditas tercipta karena komoditas tersebut memiliki kegunaan dan keterbatasan di pasar. Permintaan juga dipengaruhi oleh keinginan untuk memuaskan kebutuhan tetapi dibatasi oleh kemampuan daya beli. Seperti pada permintaan, penawaran suatu komoditas dipengaruhi juga oleh kegunaan dan keterbatasan di pasar. Suatu komoditas akan disediakan di pasar apabila dapat memberikan kepuasan kepada pembelinya. Apabila daya beli masyarakat menurun maka penawaran suatu komoditas akan berkurang, sebaliknya apabila daya beli masyarakat meningkat maka penawaran suatu komoditas akan meningkat pula. Lebih lanjut adalah beberapa teori yang berkaitan dengan harga tanah.

\section{ANALISIS PENGARUH KONSOLIDASI LAHAN TERHADAP HARGA TANAH DI RINGINTELU, KELURAHAN KALIPANCUR - KOTA SEMARANG}

Analisis pengaruh konsolidasi lahan perkotaan terhadap harga tanah yang dilakukan di Ringintelu, Kelurahan Kalipancur terdiri dari 4 tahapan analisis. Tahapan tersebut meliputi identifikasi pelaksanaan konsolidasi lahan di Ringintelu Kelurahan Kalipancur Kota Semarang, analisis faktor-faktor yang berpengaruh terhadap harga tanah di Ringintelu, analisis hubungan kausalistik konsolidasi lahan denan harga tanah di Ringintelu dan analisis pengaruh konsolidasi lahan terhadap harga tanah di Rigintelu.

\section{Identifikasi Pelaksanaan Konsolidasi Lahan di Ringintelu, Kelurahan Kalipancur - Kota Semarang}

Pelaksanaan konsolidasi lahan di Kelurahan Kalipancur Kota Semarang sesuai dengan kaidah konsolidasi yang berlaku di Indonesia, sebagaimana dimuat dalam Peraturan Kepala Badan Pertanahan Nasional Nomor 4 Tahun 1991 tentang Konsolidasi Tanah, dan yang menjadi dasar pelaksanaan konsolidasi tanah di Indonesia hingga saat ini adalah kebijakan pertanahan mengenai penataan kembali penguasaan, pemilikan, penggunaan dan pemanfaatan tanah serta usaha pengadaan tanah untuk kepentingan pembangunan untuk meningkatkan kualitas lingkungan dan pemeliharaan sumberdaya alam dengan melibatkan partisipasi aktif masyarakat. Namun, konsolidasi di Kalipancur ini dilakukan dalam skala kecil. Konsolidasi lahan di Kalipancur ini dapat dikatakan merupakan konsolidasi tidak murni karena konsolidasi dilakukan dalam skala kecil. Konsolidasi berhasil dalam hal penataan, menambah dan memperbaiki kualitas sarana dan prasarana fisik lingkungannya. Konsolidasi lahan juga memberi kepastian hukum kepemilikan lahan yaitu yang semula berstatus Hak Guna Bangunan menjadi Hak Milik. 


\section{Analisis Faktor-Faktor yang Berpengaruh terhadap harga tanah di Ringintelu, Kelurahan Kalipancur - Kota Semarang}

Faktor-faktor yang relevan dengan harga tanah sebelum dan sesudah konsolidasi lahan di Kelurahan Kalipancur adalah sama. Hal ini sejalan dengan yang diungkapkan oleh Idham, dkk dalam bukunya konsolidasi tanah dalam perspektif otonomi daerah (2004) maupun yang dikemukakan oleh Hermit (2009) yang menyebutkan bahwa faktor-faktor konsolidasi meliputi faktor aksesibilitas, pengembangan sarana prasarana fisik lingkungan serta faktor lain. Faktor lain meliputi faktor status tanah, letak posisi lahan, bentuk ukuran dan lebar muka bidang dan juga faktor eksternal lain seperti topografi, banjir, rawan longsor, peruntukan lahan, kondisi bangunan, dan arsitektur bangunan serta keamanan lingkungan. Keberadaan faktor-faktor tersebut setelah dihitung berdasarkan time value of money nya maka diketahui bahwa sesudah dilakukan konsolidasi lahan, maka harga tanah meningkat. Harga tanah meningkat tinggi antara 400\% hingga 900\% apabila dihitung berdasarkan harga pasar tahun 2013. Hal ini selaras dengan faktor-faktor yang menjadi dasar penilaian obyek pajak di Kota Semarang yang meliputi kepadatan, jarak dari pusat kota/kegiatan, kondisi jalan, ketersediaan sarana prasarana bebas banjir dan bebas longsor (Sutawijaya, 2004).

\section{Analisis Hubungan Kausailitik antara Konsolidasi Lahan dan Harga Tanah di Ringintelu, Kelurahan Kalipancur - Kota Semarang}

Hasil analisis menggunakan crosstab dan regresi berganda menunjukkan bahwa terdapat hubungan antara konsolidasi lahan dengan harga tanah pasca konsolidasi.

- Sifat hubungan lemah/tidak nyata jika hubungan dilihat antara program konsolidasi lahan dengan harga tanah sebelum konsolidasi dilaksanakan.

- Sifat hubungan erat/kuat jika hubungan dilihat dari harga tanah sesudah konsolidasi dilaksanakan dengan program konsolidasi lahan.

Erat/lemah sifat hubungan ini menunjukkan adanya pengaruh antara program konsolidasi dengan harga tanahnya. Konsolidasi memberi pengaruh pada kenaikan harga tanah. .

Data menunjukkan pasca konsolidasi lahan atau setelah terbitnya sertifikat tanah dan setelah sarana dan prasarana terbangun lengkap, harga tanah lokasi konsolidasi di Ringintelu langsung naik sebesar dalam kisaran $400 \%$ hingga 900\% dari harga transaksi awal. Hasil analisis crosstab menunjukkan bahwa 75\% dari 60 responden menyatakan sebelum konsolidasi aksesibilitasnya rendah sedangkan setelah konsolidasi $82 \%$ responden menyatakan aksesibilitas berubah menjadi tinggi. Kasus sama terjadi pada pengembangan sarana prasarana fisik lingkungannya. 77\% responden menyatakan bahwa pengembangan berada pada kategori rendah. Setelah konsolidasi dilakukan kondisi sarana prasana menjadi baik dan lengkap yang dinyatakan oleh $78 \%$ responden.

Konsolidasi lahan perkotaan ternyata mempunyai hubungan dengan harga pasar tanah setelah dikonsolidasi (harga pasar tanah tahun 2013). Hubungan yang terjadi adalah kurang nyata dengan nilai chi square kurang dari 0,05 atau tepatnya 0,026. Hal ini berarti bahwa hipotesis ditolak, artinya terdapat hubungan berupa pengaruh konsolidasi lahan perkotaan terhadap harga tanah sesudah konsolidasi meskipun tidak langsung. Sedangkan untuk akses dan pengembangan sarana prasarana fisik sesudah konsolidasi ternyata memiliki hubungan yang kuat dengan chi square nilai signifikasinya 0,000. Rentang korelasi terkuat adalah aksesibilitas setelah konsolidasi dilakukan yaitu sebesar 0,318 sampai 0,682. Rentang korelasi selanjutnya adalah pengembangan sarana prasarana yaitu -0,056 hingga 0,292. Hal ini dimungkinkan karena aksesibilitas dan pengembangan sarana prasarana tercipta sebagai akibat dari adanya program konsolidasi lahan perkotaan. Disini program konsolidasi sedikit banyak 
mempengaruhi harga tanah sesudah konsolidasi tetapi tidak berlaku sebaliknya. Kondisi yang terjadi adalah semakin tinggi aksesibilitasnya maka harga tanah akan semakin naik, demikian juga dengan sarana prasarana fisik lingkungannya.

Pengujian dengan menggunakan alat analisis regresi, sebelum konsolidasi dilakukan didapat hasil $\mathrm{F}$ hitung sebesar 11,944 atau lebih besar dari F table $(3,05)$. Demikian juga dengan $\mathrm{t}$ hitung sebesar 2,451 atau lebih besar dari t table $(1,67)$. Pengaruh ini didukung dengan data harga pasar tahun2008 yang menunjukkan adanya harga transaksi yang beragam. Setelah dilakukan konsolidasi lahan yang terjadi adalah $\mathrm{F}$ hitung menjadi 35,905 atau lebih besar dari $\mathrm{F}$ table $(3,05)$ dan t hitung menjadi 21,704 atau lebih besar dari t table $(1,67)$. Hal yang sama terjadi pada waktu dilakukan pengujian terhadap aksesibilitas dan sarana prasarana lingkungannya. Kondisi ini didukung dengan data harga pasar tahun 2013 (setelah konsolidasi secara keseluruhan selesai dilaksanakan).

Selain aksesibilitas dan pengembangan sarana dan prasarana, masih ada variable-variabel lain yang memberi pengaruh terhadap harga tanah sesudah konsolidasi lahan. Beberapa responden (18\% responden) menyatakan variable lain tersebut relative penting. Variable lain tersebut meliputi status tanah, bentuk ukuran lebar muka tanah serta tingkat kerawanan terhadap bencana alam. Hal ini menunjukkan bahwa konsolidasi lahan yang dilakukan memberi pengaruh terhadap penentu harga tanah karena naiknya status tanah yang semula HGB dan Eigendom berubah menjadi HM. Kenaikan status tanah dari konsolidasi ini juga memberi manfaat lain dalam bidang perekonomian karena dengan status tanah hak milik memudahkan mereka dalam mendapat bantuan modal dengan menjaminkan sertifikatnya ke pihak bank. Kondisi diperkuat dengan terus naiknya harga tanah pasca dilakukan program konsolidasi hingga harga tanah sama dengan harga tanah di luar lokasi konsolidasi lahan.

\section{Analisis Pengaruh Konsolidasi Lahan terhadap Harga Tanah di Ringintelu, Kelurahan Kalipancur Kota Semarang}

Hasil analisis dengan teknik crosstab dan regresi menunjukkan bahwa terdapat hubungan tidak langsung dengan adanya program konsolidasi lahan perkotaan terhadap harga tanah di Kelurahan Kalipancur Kota Semarang. Semakin tinggi akseibilitas dan kelengkapan sarana prasarananya, maka akan semakin tinggi juga harga tanahnya. Pengaruh tersebut adalah terjadinya kenaikan harga tanah pada lokasi konsolidasi lahan perkotaan di Kelurahan Kalipancur. Pengaruh tidak mutlak karena disamping program konsolidasi lahan terdapat faktor/variable lain yang mempengaruhi harga lahan baik faktor internal maupun factor eksternalnya. Faktor lain tersebut meliputi letak posisi bidang tanah, bentuk ukuran dan lebar muka bidang, topografi yang berkaitan dengan tingkat kerawanan seperti banjir, longsor dan genangan air. Hasil test menggunakan crosstab menunjukkan bahwa terdapat hubungan antara konsolidasi lahan dengan harga tanah sesudah dikonsolidasi. Konsolidasi lahan dapat digunakan untuk memprediksi/mempengaruhi harga lahan sesudah dilakukan program konsolidasi lahan. Ketika dilakukan test untuk program konsolidasi lahan dengan variable aksesibilitas, hasil menunjukkan hubungan yang cukup kuat/erat, aksesibilitas dapat digunakan untuk memprediksi harga lahan sesudah program konsolidasi lahan dilakukan. Semakin tinggi aksesibilitasnya maka harga tanahnya juga akan semakin tinggi. Demikian halnya dengan sarana dan prasarana fisik lingkungannya, semakin lengkap dan baik sarana dan prasarana fisik lingkungannya maka akan semakin tinggi juga harta tanahnya. Hasil tes menggunakan regresi didapat hal yang senada yaitu terdapat hubungan antara konsolidasi lahan dengan harga tanah di Ringintelu. Meskipun pada kenyataannya harga tanah juga dipengaruhi oleh variable lain seperti letak posisi tanah lengkap dengan bentuk dan ukuran serta lebar mukanya, topografi tanah yang berkaitan dengan kerawanan bencana seperti banjir dan longsor. Artinya memang 
terdapat pengaruh adanya program konsolidasi lahan perkotaan terhadap harga tanah di Kelurahan Kalipancur Kota Semarang. Pengaruh tersebut ditandai munculnya kelompok harga tanah:

a. Kelompok I harga tanah (harga pasar Rp.1.200.000,-) dengan aksesibilitas tinggi, sarana dan prasarana hasil konsolidasi lengkap dan kondisi baik serta bentuk ukuran lebar kapling besar;

b. Kelompok II harga tanah (harga pasar Rp. 1.100.000,-) dengan aksesibilitas tinggi, sarana dan prasarana hasil konsolidasi lengkap serta kapling kecil;

c. Kelompok III harga tanah (harga pasar Rp.1.000.000,-) dengan akses sedang dan sarana prasarana hasil konsolidasi lengkap;

d. Kelompok IV harga tanah (harga pasar Rp.900.000,-) dengan aksesibilitas rendah, kapling kecil serta terkena polusi pabrik (dinding menempel tembok pabrik, efek getar dan polusi suara serta adanya getaran dari aktivitas jalan tol)

e. Kelompok $\mathrm{V}$ harga tanah (harga pasar Rp.850.000) dengan akses rendah dan rawan longsor.

Hal di atas terlihat bahwa semakin tinggi aksesibilitasnya maupun sarana prasarananya maka akan semakin tinggi juga harga tanahnya. Program konsolidasi lahan disini ikut memberi pengaruh terhadap harga tanah di Kelurahan Kalipancur Kota Semarang. Hal ini, tujuan dari konsolidasi lahan dapat tercapai meskipun tidak secara mutlak mengingat konsolidasi lahan dilakukan dalam skala kecil kawasan.

Jadi, berdasar hasil analisis yang telah dilakukan maka jawaban research question bagaimana hubungan antara konsolidasi lahan perkotaan dengan harga tanah di Ringintelu pada penelitian Pengaruh Konsolidasi Lahan Perkotaan terhadap Harga Tanah di Kelurahan Kalipancur Kota Semarang, adalah terdapat hubungan antara konsolidasi lahan perkotaan terhadap harga tanah di Kelurahan kalipancur Kota Semarang. Hubungan berupa kenaikan harga tanah (berdasar harga pasar tahun 2013) yang secara tidak langsung dipengaruhi oleh adanya program konsolidasi. Pengaruh dikatakan tidak langsung karena faktor-faktor seperti aksesibilitas dan pengembangan sarana dan prasarana terjadi melalui program konsolidasi lahan. Pengaruh tersebut tidak hanya dari adanya program konsolidasi lahan saja, melainkan karena adanya factor lain seperti posisi tanah, ukuran tanah dan topografi yang berimbas pada rawan bencana seperti genangan air pada waktu hujan, banjir dan juga rawan longsor.

\section{KESIMPULAN}

Berdasarkan hasil penelitian diketahui bahwa program konsolidasi lahan perkotaan berpengaruh secara tidak langsung terhadap harga tanah di Ringintelu, Kelurahan Kalipancur. Pengaruh dikatakan tidak langsung karena faktor-faktor yang mempengaruhi harga tanah terjadi sebagai akibat adanya program konsolidasi lahan perkotaan. Program konsolidasi lahan ini meskipun dilakukan dalam skala kecil dapat menjadi salah satu solusi dalam pengadaan tanah untuk mengatasi kebutuhan lahan di Kota Semarang. Hal ini ditunjukkan dengan adanya hubungan erat/kuat antara konsolidasi lahan perkotaan dengan harga tanah (harga transaksi/pasar tahun 2013) dengan rentang korelasi sebesar 0,318 sampai dengan 0,682 atau mendekati 1 (syarat kuat bila mendekati 1 atau di atas 0,05) dan nilai chi squarenya sebesar 0,026 . Hal yang sama ketika diuji dengan analisis regressi, yang menunjukkan konsolidasi lahan (dengan variabel aksesibilitas dan pengembangan sarana prasarana) memberi pengaruh sebesar $81,1 \%$ terhadap harga tanah dan sisanya sebesar 18,9\% dipengaruhi oleh variavel lain seperti letak posisi bidang tanah, bentuk dan ukuran serta lebar muka bidang tanah, 
penggunaan dan pemanfaatan serta tingkat kerawanan terhadap bencana. Dari analisis di atas dapat disimpulkan bahwa harga tanah naik seiring perkembangan fisik lingkungannya dan semakin tinggi aksesibilitas atau sarana prasarananya maka semakin tinggi juga harga tanahnya.

\section{DAFTAR PUSTAKA}

Eckert, J.K. 1990. Property Appraisal and Assessment Administration, IAAO. Chicago Illinois. Hermit, Herman. 2009. Teknik Penaksiran Harga Tanah Perkotaan. Bandung: Mandar Maju. Idham, dkk. 2004. Konsolidasi Tanah dalam Perspektif Otonomi Daerah. Bandung: PT Alumni.

Noor M, Abd. Rahman. 1997. Penilaian Harta Tanah, Program Kerjasama BPLK dengan ITM Mura Malaysia, Malang.

Pearce, David W., and Turner Kerry R. 1990. Economics of Natural Resources and the Enviroment, the John Hopkins University, Baltimore.

Peraturan KaBPN No.4 tahun 1991 Tentang Konsolidasi Tanah.

Sadyohutomo, Mulyono. 2008. Manajemen Wilayah dan Kota: Realita dan Tantangan. Jakarta: Bumi Aksara.

Setiawan, Yudhi. 2008. Konsolidasi Tanah dari Perspektif Filsafat Ilmu. Jurnal IImiah Edisi IX Nomor 1.

Sumardjono, Maria S.W. 1990. Aspek Yuridis dan Sosial Ekonomi dalam Pelaksanaan Konsolidasi Pertanahan. Makalah pada : Lokakarya KTP, Semarang, 12-13 Desember.

Sutawijaya, Adrian. 2004. Faktor-faktor yang Mempengaruhi Nilai Tanah sebagai Dasar Penilaian NJOP PBB di Kota Semarang. Jurnal Ekonomi Pembangunan Vol. 2 Juni.

Yuriwin, Ari. 2010. Bahan Ajar Konsolidasi Tanah. Jakarta: Dirktbpnri. 